\title{
Plasma Lipids and Lipoproteins in Friedreich's Ataxia and Familial Spastic Ataxia - Evidence for an Abnormal Composition of High Density Lipoproteins
}

\author{
Y. S. HUANG, A. C. NESTRUCK, A. BARBEAU, J. P. BOUChARD, AND J. DAVIGNON.
}

\begin{abstract}
SUMMARY: $A$ systematic study of plasma lipids and lipoproteins was carried out in 11 cases of Friedreich's ataxia and 6 cases of familial spastic ataxia (Charlevoix-Saguenay disease) using $1 /$ healthy normolipidemic volunteers of comparable age and sex as controls. No differences were noted in the fatty acid profile of the total lipid fraction, in the total cholesterol and phospholipids or in the percentage distribution of the individual phospholipid classes. The triglycerides were significantly higher in Friedreich's ataxia, but remained within the normal range. Although no systematic abnormalities could be detected in the electrophoretic pattern of plasma lipoproteins or in the apolipoprotein profile on polyacrylamide gel electrophoresis, major differences
\end{abstract}

RÉSUME: Une étude systématique des lipides et des lipoprotéines plasmatiques a été accomplie chez II cas d'Ataxie de Friedreich et 6 cas d'Ataxie spastique familiale (Maladie de CharlevoixSaguenay) utilisant 10 volontaires normolipidémiques, bien portants, d'âge et de sexe comparables comme sujets témoins. Aucune différence notable n'a été mise à jour tant pour le profil des acides gras des lipides totaux que pour le cholestérol, les phospholipides et la répartition des différentes classes de phospholipides circulants. Les triglycérides étaient plus élevés dans l'Ataxie de Friedreich, mais la moyenne demeurait dans les limites de la normale. Bien qu'on n'ait pu mettre en évidence d'anomalie systématique dans le tableau électrophorétique des lipoprotéines

From the Clinical Research Institute of Montreal and l'Hôpital de l'Enfant Jésus, Quebec.

Reprints requests for the entire supplement on Friedreich's Ataxia (Phase Two, Part One) to: Dr. André Barbeau, Clinical Research Institute of Montreal, 110 Pine Avenue West, Montreal, Quebec, H2W 1R7 Canada. were found in the high density lipoprotein (HDL) fraction. Their total amount was reduced and their composition was abnormal in both neurological diseases. In Friedreich patients, the relative proportion of cholesterol and triglycerides was increased while the relative protein content was greatly redaced. In Charlevoix disease, a similar abnormality was seen except for the excess of triglycerides. The proportion of phospholipids in $H D L$ was the same in the three groups of patients. In addition, the low density lipoprotein ( $L D L)$ fraction was slightly reduced in both diseases. This anomaly of the HDL fraction could indicate that the $H D L$ apolipoprotein moiety has a greater affinity for cholesterol and triglycerides in Friedreich's ataxia than its normal counterpart.

plasmatiques, pas plus que dans le profil des apolipoprotéines séparées sur gel de polyacrylamide, des différences importantes ont été notées au niveau des lipoprotéines de haute densité (HDL). Leur teneur était réduite dans le plasma et leur composition était anormale dans les 2 maladies neurologiques étudiées. Dans le Friedreich, la proportion de cholestérol et de triglycérides dans cette fraction était augmentée tandis que le contenu en protéines était considérablement réduit. Dans la maladie de Charlevoix, on retrouvait un tableau similaire sans toutefois qu'il y ait une augmentation des triglycérides. La proportion de phospholipides des $H D L$ demeurait la même dans les 3 groupes de sujets. De plus, les lipoprotéines de faible densité (LDL) étaient légèrement réduites dans les 2 maladies. Cette anomalie inédite des HDL pourrait indiquer que leur composante apolipoprotéique possède une affinité plus grande pour le cholestérol et les triglycérides dans la maladie de Friedreich si on utilise comme point de comparaison des HDL normales.

\section{INTRODUCTION}

It is known that certain neurological diseases are associated with plasma lipid abnormalities (Steinberg, 1972; Mueller and Quick, 1970). Inversely, abnormalities of plasma lipid transport may give rise to neurological manifestations (Fredrickson et al., 1972; Mars et al., 1969; Fessel, 1971; Sandbank et al., 1971; Sandbank and Bubis, 1973). It has been shown that the feeding of certain unnatural fatty acids in man may induce symptoms of peripheral neuropathy (Mishkel and Spritz, 1969). More recently, it has even been demonstrated, in a hyperlipidemic patient, that symptoms of dementia could vary with changes in plasma lipid levels (Heilman and Fisher, 1974).

We report the result of a survey of the various plasma lipid and lipoprotein fractions in Friedreich's Ataxia and in a closely related disorder, using a matched sample of comparable size of normolipidemic subjects for controls. This study revealed an abnormal composition of plasma high density lipoproteins in Friedreich's ataxia and familial spastic ataxia.

\section{MATERIAL AND METHODS}

\section{Subjects:}

The study was carried out on 11 patients affected with Friedreich's ataxia as defined by the criteria of the QCSFA (Barbeau, 1976), between the ages of 23 and 37 y (5 males, 6 females). They were compared with 10 normolipidemic healthy volunteers of similar age and sex distribution and free of any 
TABLE 1

CHARACTERISTICS OF SUBJECTS STUDIED

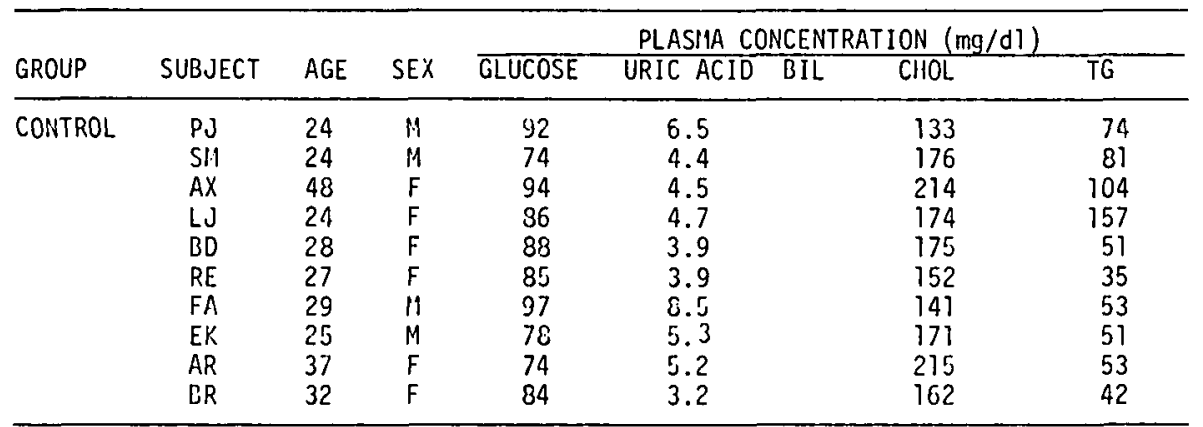

\begin{tabular}{lcccccccc}
\hline $\bar{x} \pm$ SD & & $29.8 \pm 7.6$ & & $35.2 \pm 7.9$ & $5.0 \pm 1.5$ & & $171.3 \pm 27.1$ & $70.1 \pm 36.8$ \\
\hline FR IEDREICH & RJ & 27 & M & 110 & 6.9 & 1.40 & 183 & 132 \\
& RP & 28 & M & 102 & 5.3 & 2.90 & 142 & 109 \\
& LM & 24 & $\mathrm{~F}$ & 96 & 3.7 & 1.60 & 172 & 60 \\
& AA & 24 & M & 94 & 6.5 & - & 112 & 136 \\
& AD & 25 & $\mathrm{~F}$ & 92 & 3.9 & - & 150 & 132 \\
& AG & 27 & $\mathrm{~F}$ & 316 & 2.7 & 1.48 & 200 & 33 \\
& SL & 23 & M & 90 & 4.6 & 1.20 & 98 & 39 \\
& LC & 37 & $\mathrm{~F}$ & 78 & 3.3 & 0.70 & 188 & 109 \\
& GM & 28 & M & 102 & 4.7 & - & 134 & 125 \\
& CD & 32 & $F$ & 276 & 2.2 & 0.40 & 203 & 127 \\
& FF & 25 & $F$ & 80 & 4.7 & 0.40 & 216 & 157
\end{tabular}

\begin{tabular}{lccccccc}
\hline $\bar{x} \pm$ SD & & $27.2 \pm 4.1$ & $130.5 \pm 82.3$ & $4.4 \pm 1.4$ & $163.9 \pm 39.5$ & $114.5 \pm 41.4$ \\
\hline CHARLEVOIX & CC & 24 & $M$ & 71 & 3.0 & 184 & 173 \\
& CP & 16 & $M$ & 84 & - & 153 & 176 \\
& CS & 12 & $M$ & 70 & 2.9 & 148 & 76 \\
& MY & 28 & $F$ & 81 & 2.9 & 168 & 42 \\
& SA & 23 & $M$ & 83 & 5.3 & 109 & 36 \\
& JA & 32 & $\mathrm{~F}$ & 90 & 3.8 & 154 & 76 \\
\hline
\end{tabular}

\begin{tabular}{llllll}
\hline $\bar{x} \pm$ SD & $22.5 \pm 7.4$ & $30.6 \pm 8.4$ & $3.5 \pm 1.0$ & $153.5 \pm 25.2$ & $96.5 \pm 62.7$
\end{tabular}

Abbreviations: $B I L=$ bilirubin $; \quad$ CHOL $=$ cholesterol.

neurological impairment, and 6 cases suffering from a recessive form of spastic ataxia. The latter is closely related to Friedreich's ataxia although distinctive. The discovery of this disease has been described under the name of CharlevoixSaguenay syndrome by Bouchard et al. in this issue.

The characteristics of the subjects are given in Table 1. It should be noted that 3 of the 11 cases of Friedreich's ataxia had abnormalities of glucose metabolism. About half of the patients were in the hyperbilirubinemic subgroup (plasma total bilirubin concentration $\geq 1.1 \mathrm{mg} / \mathrm{d}$ l) (Barbeau et al., 1976).

\section{Blood Sampling:}

Venous blood for plasma lipid and lipoprotein analyses was obtained in the morning after a 12-hour fast. The sample was withdrawn into tubes which contained disodium EDTA (1 mg per milliliter of blood), immediately cooled and centrifuged at $4^{\circ} \mathrm{C}$ at $1120 \mathrm{~g}$ for 10 minutes. The prepared plasma was kept at $4^{\circ} \mathrm{C}$ and processed within 24 hours for the study of lipoprotein fractions. Other aliquots were either processed immediately or stored at $-20^{\circ} \mathrm{C}$ for determination of plasma lipid fractions at a later time. On each sample, glucose (Glucose procedure N-2b, in AutoAnalyzer Manual [1965], Chauncey, N.Y., Technicon Instruments Corps and uric acid (Uric acid Procedure $\mathrm{N}-13 \mathrm{~b}$, in $\mathrm{Au}$ toAnalyzer Manual [1965], Chauncey, N.Y. Technicon Instruments Corp.) was measured.

\section{Lipid measurements:}

Total plasma cholesterol, and cholesterol of the plasma lipoprotein fractions were measured by the method of Block et al. (1966) with a Technicon AutoAnalyzer (Total cholesterol Procedure N-24a. In AutoAnalyzer Manual [1965], Chauncey, New York, Technicon Instruments Corp.). Triglycerides were measured by the method of Laurell (1966) adapted to the AutoAnalyzer by Kraml and Cosyns (1969) both in the plasma and in the various lipoprotein fractions. Phospholipids were measured in plasma and in the high density lipoprotein fraction by the method of Bartlett (1959). This method was also used for the measurement of lipid phosphorus in the major phospholipid classes separated by thin layer chromatography (Noël et al, 1972). For the measurement of the fatty acid profile, the total lipid fraction was extracted from plasma according to the method of Folch et al. (1957) modified by Bragdon (1960). It was hydrolyzed at $70^{\circ} \mathrm{C}$ for 90 minutes with 1 $\mathrm{N} \mathrm{KOH}$ in a $70 \%$ methanol solution and the methyl esters of the fatty acids were prepared as described by Metcalfe et al. (1966). The latter were quantitated by gas liquid chromatography on a 6-foot U-shaped glass column packed with 10\% Silar-10 on Gas Chrom Q 100-120 mesh (Applied Sciences) at $185^{\circ} \mathrm{C}$ using a Hewlett-Packard $\mathrm{F} \&$ $M$ model 402 apparatus equipped with an hydrogen flame ionization detector at a hydrogen flow rate of $30 \mathrm{ml}$ per min. The fatty acid profile was not examined in the Charlevoix-Saguenay syndrome. The blood samples in these subjects were obtained in the field and the amount of plasma was insufficient to perform all the lipid determinations. For most determinations, there was enough plasma in only 5 of the 6 Charlevoix patients.

\section{Lipoprotein and apolipoprotein analyses:}

Lipoproteins were separated by two different methods. The standard combination of ultracentrifugation at a density of $1.006 \mathrm{~g} / 1$ and dextran sulfate precipitation as described by Hatch and Lees (1968) was used. This technique combined with paper 
TABLE 2 PERCEITAGE COMPOSITION OF PLASHA FATTY ACIDS

\begin{tabular}{ccc}
\hline FATTY ACIDS & $\begin{array}{c}\text { CCNTROL } \\
(n=10)\end{array}$ & $\begin{array}{c}\text { FRIEDEICH'S ATAXIA } \\
(n=1))\end{array}$ \\
\hline $14: 0$ & $0.60 \pm 0.49 *$ & $0.60 \pm 0.49$ \\
$16: 0$ & $21.47 \pm 2.03$ & $22.07 \pm 1.78$ \\
$16: 1$ & $3.08 \pm 1.03$ & $3.20 \pm 1.16$ \\
$18: 0$ & $6.98 \pm 1.44$ & $7.01 \pm 1.54$ \\
$18: 1$ & $24.30 \pm 4.10$ & $27.25 \pm 3.65$ \\
$18: 2$ & $33.97 \pm 0.37$ & $32.12 \pm 4.57$ \\
$10: 3$ & $0.48 \pm 0.34$ & $0.16 \pm 0.08$ \\
$20: 4$ & $7.94 \pm 1.63$ & $7.32 \pm 1.44$ \\
$22: 0$ & $0.82 \pm 0.53$ & $0.84 \pm 0.56$ \\
\hline
\end{tabular}

$\star$ mean \pm SO. electrophoresis (Lees and Hatch, 1963) on the various fractions obtained is currently used in our laboratory for the evaluation of hyperlipidemic patients (Davignon and Langelier, 1971). The electrophoresis is carried out on the whole plasma, on the supernatant of the dextran sulfate precipitate representing the alphalipoprotein fraction, on the 1.006 ultracentrifugal bottom fraction containing both the alphalipoproteins (high density lipoprotein, HDL) and the betalipoproteins (low density lipoprotein, LDL) and on the 1.006 top fraction containing the prebetalipoprotein fracVLDL). Cholesterol and triglycerides are measured in the first 3 fractions, so that by difference the proportion of these lipids in the 4 classes of lipoproteins can be obtained. A sequential ultracentrifugation at densities $1.006,1.063$ ing to the technique of Havel et al. (1965) to separate VLDL, LDL and HDL respectively. This allowed for the measurement of the protein content (Lowry et al., 1951) of each of these lipoprotein classes as well as for the determination of phospholipids in the HDL fraction. In this technique, both LDL and HDL fractions are dialyzed against $0.15 \mathrm{M}$ $\mathrm{NaCl}$ containing $1 \mathrm{mM}$ EDTA $(\mathrm{pH}$ 7.4) to get rid of the excess $\mathrm{KBr}$ used for density adjustment. The sepation (very low density lipoprotein, and $1.21 \mathrm{~g} / 1$ was carried out accord- rated VLDL and HDL were used for delipidation and study of their apolipoprotein moiety.

The apolipoproteins were studied by polyacrylamide gel electrophoresis after delipidation on the top of the gel by tetramethylurea according to the method of Kane et al. (1973, 1975). Approximately 100 $\mu \mathrm{g}$ of protein is applied on each gel. The electrophoresis is carried out on $7.5 \%$ gels in $8 \mathrm{M}$ urea for 3-hour at $4^{\circ} \mathrm{C}$ with a constant current of 2.5 $\mathrm{mA}$ per tube. The gels are fixed and stained for protein with $0.25 \%$ Coomassie blue in $45 \%$ methanol and $9.2 \%$ acetic acid for 1 hour (Bachorik et al., 1974). In a few instances the apolipoproteins were studied by sodium dodecyl sulfate (SDS)-polyacrylamide gel electrophoresis according to the methods of Shapiro et al. (1967) and Weber and Osborn (1969). In these cases the procedure of delipidation was that of Scanu and Edelstein (1971).

\section{RESULTS}

The fatty acid profile of the plasma total lipid fraction was the same in the Friedreich's ataxia patients and in the control subjects. None of the values for the percentage composition of plasma fatty acids given in Table 2 were significantly different between the two groups.

While total plasma cholesterol did $\underline{\text { TABLE } 3}$

PLASMA PHICSPIIOLIPIOS COMPOSITION

\begin{tabular}{|c|c|c|c|c|}
\hline & & $\begin{array}{l}\text { CONITROL } \\
(n=10)\end{array}$ & $\begin{array}{l}\text { FRIEDREICH } \\
(\mathrm{n}=11)\end{array}$ & $\begin{array}{l}\text { CHARLEVOIX } \\
(n=6)\end{array}$ \\
\hline TOTAL & PL & $221.9 \pm 13.6^{*}$ & $218.8 \pm 11.6$ & $201.0 \pm 9.9$ \\
\hline (is) & $\mathrm{PE}$ & $4.7 \pm 0.6$ & $4.0 \pm 0.6$ & $5.9+1.0$ \\
\hline (\%) & PC & $68.8 \pm 1.1$ & $68.7 \pm 0.7$ & $66.2 \pm 1.8$ \\
\hline$(:)$ & $s$ & $13.1 \pm 0.5$ & $18.2 \pm 0.6$ & $18.3 \pm 0.3$ \\
\hline (Z) L & LPC & $8.4 \pm 0.5$ & $9.2 \pm 0.9$ & $9.6+3.1$ \\
\hline
\end{tabular}

$$
\begin{aligned}
P C & =\text { phosphatidylchol ine; } \\
S & =\text { sphingomel in; } \\
P C & =\text { lysophosphatidylcholine; }
\end{aligned}
$$

not significantly differ in the three groups of patients (Table 1 and Table 4), the plasma triglycerides were higher among the Friedreich patients $(p<0.02)$ although only one subject, RJ, had abnormally high concentrations. The individual values, however, varied greatly from patient to patient.

The total plasma phospholipid levels were the same in the three groups of patients (Table 3). There were no statistically significant differences in the relative proportion of the various lipoprotein classes although lysophosphatidylcholine (LPC, lysolecithin) levels tended to be higher in hoth neurnlogical diseases.

The plasma total phospholipid/cholesterol (PL/CH) ratios did not differ between the control group (1.296 \pm 0.137 , mean $\pm S D$ ), the Friedreich patients $(1.362 \pm 0.158)$ and the patients affected with Charlevoix disease $(1.257 \pm 0.110)$. In all 3 groups the plasma cholesterol levels were closely related to the plasma phospholipid concentrations. However, as demonstrated in Figure 1, when plasma cholesterol and phospholipid concentrations are plotted against one another on a linear graph, the slope of the regression line is different between the control group and the group of patients with Friedreich's ataxia. In the lower 
TABLE 4

CIIOLESTEROL, TRIGLYCERIDE AND PROTEIN CONTENT OF THE MAUOR LIPOPROTEIN CLASSES

\begin{tabular}{lcccc}
\hline $\begin{array}{l}\text { LIPOPROTEIN } \\
\text { FRACTION }\end{array}$ & $\begin{array}{c}\text { CONTROL } \\
(n=10)\end{array}$ & $\begin{array}{c}\text { FRIEDREICH } \\
(n=11)\end{array}$ & $\begin{array}{c}\text { CHARLEVOIX } \\
(n=5)\end{array}$ \\
\hline VLOL & $\mathrm{Pr}$ & $11.5 \pm 1.7 *$ & $9.5 \pm 1.2$ & $7.6 \pm 2.8$ \\
& $\mathrm{CH}$ & $10.2 \pm 2.1$ & $21.6 \pm 3.5^{\infty}$ & $22.6 \pm 8.8$ \\
& $\mathrm{TG}$ & $40.9 \pm 10.1$ & $82.0 \pm 11.8^{\infty}$ & $60.4 \pm 22.8$ \\
\hline LDL & $\mathrm{Pr}$ & $72.7 \pm 9.4$ & $46.5 \pm 5.0^{5}$ & $47.9 \pm 6.3$ \\
& $\mathrm{Cli}$ & $126.8 \pm 7.3$ & $110.8 \pm 9.3$ & $97.3 \pm 8.3^{5}$ \\
& $\mathrm{TG}$ & $18.5 \pm 2.2$ & $15.5 \pm 1.4$ & $14.2 \pm 2.5$ \\
\hline HDL & $\mathrm{Pr}$ & $158.4 \pm 15.8$ & $75.3 \pm 10.4^{\dagger}$ & $56.0 \pm 8.1^{\dagger}$ \\
& $\mathrm{CH}$ & $34.3 \pm 2.1$ & $30.5 \pm 1.5$ & $27.0 \pm 3.3$ \\
& $\mathrm{TG}$ & $10.9 \pm 1.8$ & $17.6 \pm 1.6^{\infty}$ & $6.6 \pm 1.6$ \\
\hline \multirow{2}{*}{ TOTAL } & $\mathrm{Pr}$ & $242.6 \pm 19.8$ & $132.4 \pm 12.0^{\dagger}$ & $111.5 \pm 9.6^{\dagger}$ \\
& $\mathrm{CH}$ & $171.3 \pm 8.6$ & $163.9 \pm 11.9$ & $147.4 \pm 10.1$ \\
& $\mathrm{TG}$ & $70.1 \pm 11.6$ & $114.5 \pm 12.5^{\infty}$ & $81.2 \pm 25.1$ \\
\hline
\end{tabular}

* mean \pm SEll $(\mathrm{mg} / \mathrm{dl})$

$+p<0.001$

$\infty \mathrm{p}<0.02$

$\xi \mathrm{p}<0.05$

Abbreviations: $\mathrm{Pr}=$ protein; $\mathrm{CH}=$ cholesterol; $T G=$ triglycerides;

$V L D L=$ very low density lipoproteins; $L D L=$ low density 1 ipoproteins; HDL = high density lipoproteins.

range of plasma lipid concentrations, for a given level of plasma cholesterol, the corresponding level of plasma phospholipid is higher in the Friedreich's group than in the control group. In other words, in this range (cholesterol less than 150 $\mathrm{mg} / \mathrm{d} 1$ ), the $\mathrm{PL} / \mathrm{CH}$ ratio is lower in the Friedreich than in the control group.

The plasma lipoprotein pattern on paper electrophoresis was essentially within the variations expected from plasma lipid concentrations in Friedreich's ataxia and Charlevoix disease. There was no abnormally migrating band or traces of chylomicrons in the fasting samples. When the electrophoresis was carried out on the various lipoprotein fractions separated by ultracentrifugation and dextran sulfate precipitation, there was no evidence of a beta migrating VLDL (floating beta-lipoprotein) as seen in familial type III hyperlipoproteinemia (dysbeta-lipoproteinemia) (Aubry et al., 1971).

In contrast, measurements of the composition of the major classes of lipoproteins revealed significant differences as demonstrated in Table 4. As expected from the higher values of the total plasma triglycerides, the cholesterol and triglyceride content of the VLDL was significantly greater in the patients with Feidreich's ataxia than in the control group. There were minor differences in the protein level associated with LDL which was slightly lower in the Friedreich group, while the cholesterol concentration of this fraction was slightly less in the Charlevoix group. The most striking differences however, were seen in the HDL fraction where the protein content was lower with high statistical sig- nificance $(p<0.001)$ in both diseases as compared with the control group, while the triglyceride content was greater in the Friedreich patients only. Thus, the total lipoprotein protein content was lower in the plasma of patients affected with both neurological diseases and that occurred essentially at the expense of lower HDL protein concentrations.

A closer look at Table 4 reveals that the cholesterol content of the HDL fraction is only slightly reduced in contrast with the protein content of this fraction which is much lower in both diseases. The difference is more apparent when the protein/cholesterol ratios are measured (Table 5). This ratio is lower in both the VLDL and the HDL fractions. However, in the former it is mainly due to an increase in the cholesterol content while in the latter the reduced amount of protein is mainly responsible. In this table the protein/cholesterol ratio in the VLDL fraction was also calculated with the exclusion of the value obtained for patient SL who had an unusually low plasma triglyceride concentrations $(11 \mathrm{mg} / \mathrm{d} 1)$.

To further document the difference in HDL composition, the phospholipid content was measured in this lipoprotein class. The relative composition of the HDL fraction expressed in percentage of protein, cholesterol, triglycerides and phospholipids is presented in Table 6. The proportion of phospholipids is the same and that of triglycerides and cholesterol higher while the protein content is much lower in Friedreich's ataxia than in the control group. Except for triglycerides, a similar pattern is revealed for Charlevoix disease. This unusual composition of high density lipoproteins in Friedreich's ataxia is more clearly illustrated in the drawing of Figure 2 where it is contrasted with the normal pattern. In Figure 3, the frequency distribution curves for the three HDL components indicate that the Friedreich patients and the control subjects constitute two distinct populations.

The apolipoprotein patterns of the VLDL and the HDL lipoprotein classes in Friedreich's ataxia and 


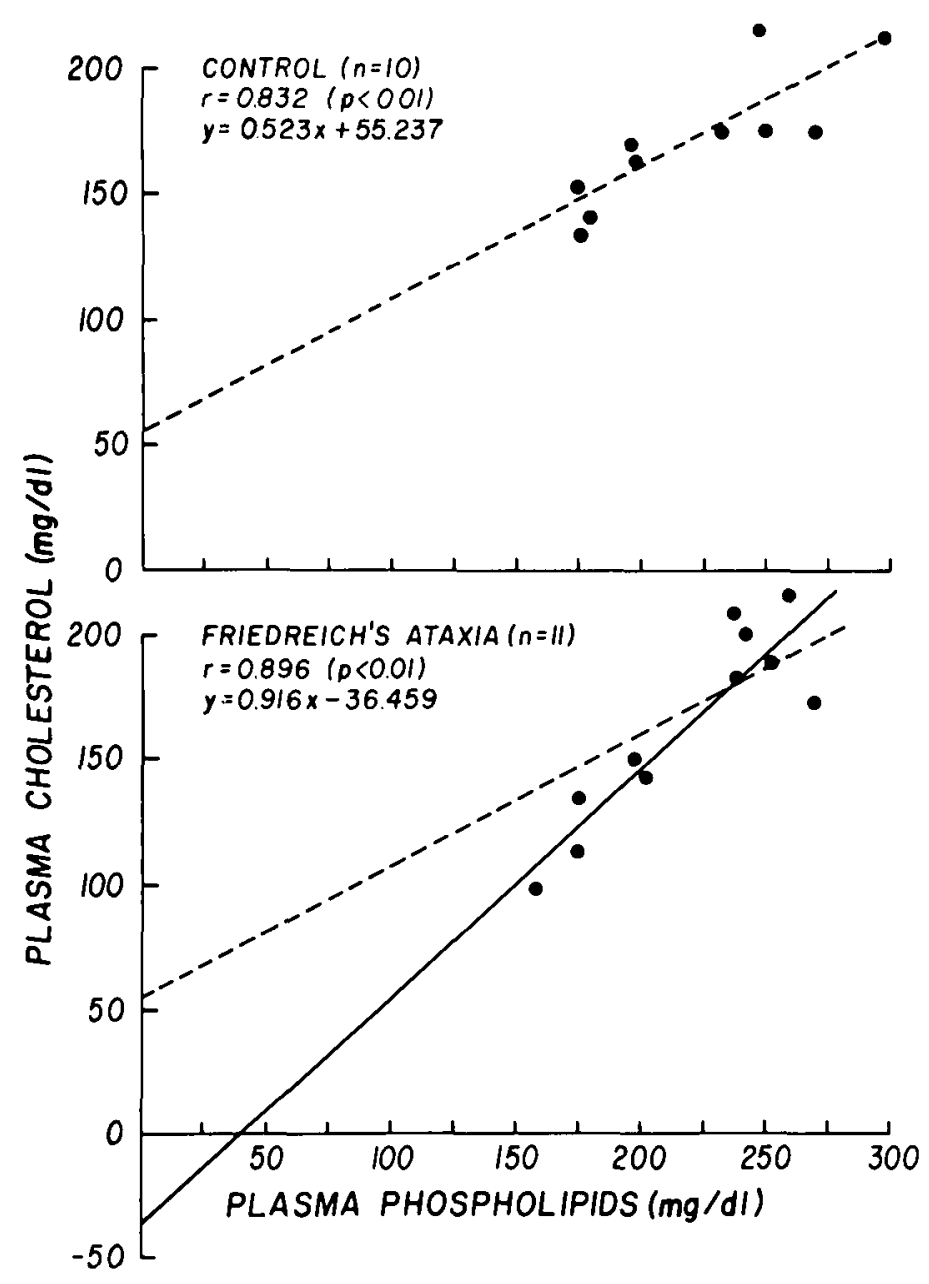

Figure 1-Correlation between total cholesterol and phospholipids in the plasma of control subjects and patients with Friedreich's ataxia.

$r=$ Pearson coefficient of correlation.
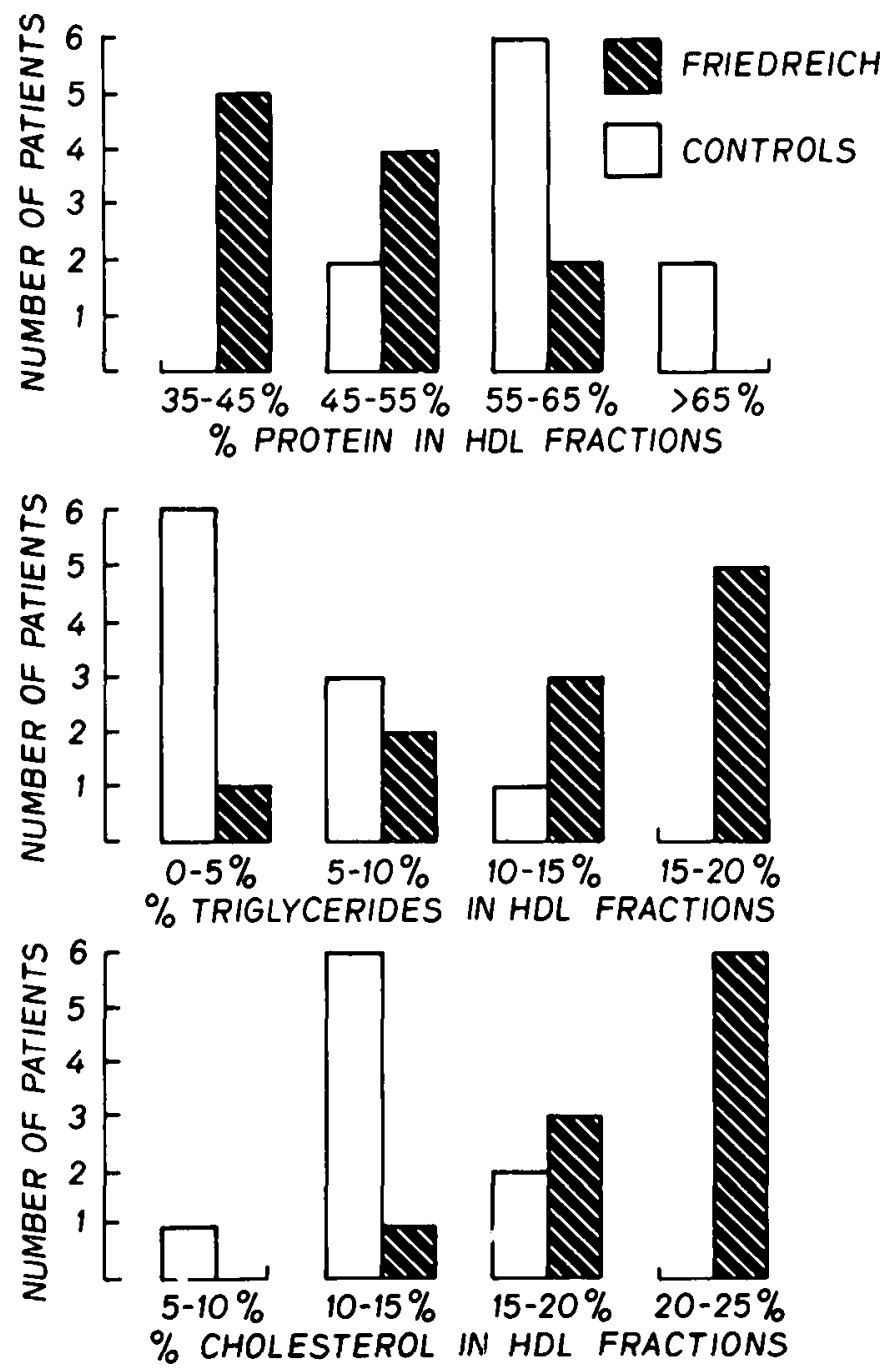

Figure 3-Frequency distribution for the $\mathrm{HDL}$ content of protein, triglycerides and cholesterol (expressed in percent) in Friedreich's ataxia patients and control subjects.
Charlevoix disease did not show any systematic differences from the patterns observed in the control groups. In two instances we have compared a Friedreich patient and a control using two other techniques (Shapiro et al., 1967; Weber and Osborn, 1969) without being able to show a difference by the simple visual observation of the gels. It is not possible to eliminate a significant quantitative difference unless more accurate measurements are made using specific antibodies to the various apolipoprotein peptides.

\section{DISCUSSION}

It has been shown that Refsum's disease, a hereditary form of ataxia and polyneuritis, is associated with an unusually large amount of a methylated 10-carbon fatty acid in plasma called phytanic acid (Steinberg, 1972). Although phytanic acid is not ele vated in Friedreich's ataxia (Steinberg, 1972), one must be aware of other anomalies of plasma fatty acids since such substances are likely candidates for the production of neurological manifestations. The "odor-of-sweaty-feet-syndrome", for instance, a lethal inborn error of short-chain fatty acid metabolism with circulating excesses of butyric and hexanoic acid, is associated with lethargy and convulsions (Sidbury et al., .1964). The feeding of large amounts of triglycerides made with 18-carbon di-unsaturated unnatural "trans-trans" fatty acids may produce symptoms of peripheral neuritis in man (Mishkel and Spritz, 1969). Our investigation of the fatty acid profile of the plasma total lipid fraction did not reveal any significant quantitative or qualitative differences from normal in both neurological diseases studied. There were no unusual peaks revealed on the chromatrograms and no evidence for the accumulation of any short chain fatty acid. The technique used, however, does not rule out the remote possibility of the presence of trans-trans or trans-cis 18:2 fatty acids which would have the same 


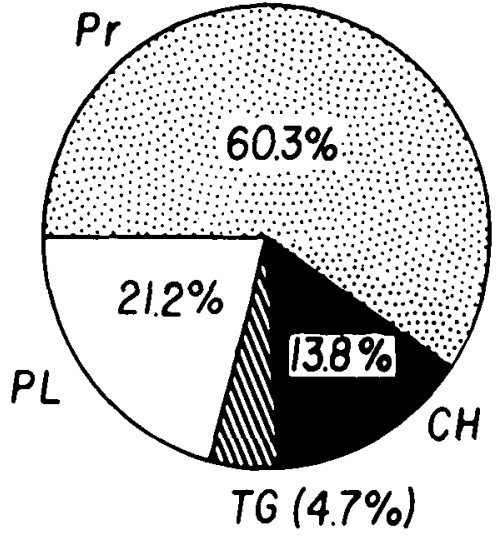

CONTROLS

$$
(n=10)
$$

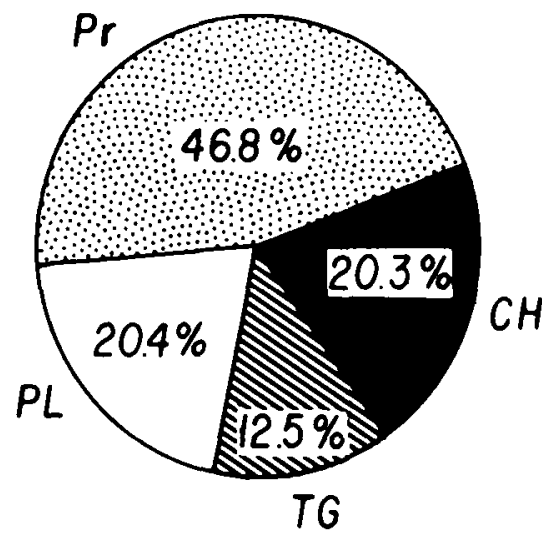

FRIEDREICH

$(n=11)$

Figure 2-Percentage composition of $\mathrm{HDL}$ in controls and in patients with Friedreich's ataxia. Abbreviations: $\mathrm{Pr}=$ Protein; $\mathrm{CH}=$ cholesterol; $\mathrm{TG}=$ triglycerides; $\mathrm{PL}=$ phospholipids.

retention time as their natural cis-cis counterpart.

We were particularly interested in the plasma phospholipid/cholesterol ratio because of its possible influence on cell-membrane composition (Cooper et al., 1975). We could not demonstrate a difference, on the average, between the three groups. However, although cholesterol and phospholipids were closely correlated in all patients, the regression line in Friedreich's ataxia had a more acute slope than in normals. The significance of this remains obscure. In Charlevoix disease, the regression line had virtually the same slope as the normal subjects. However, only one patient had a cholesterol in the lower range $(109 \mathrm{mg} / \mathrm{dl})$ where the difference was greatest between Friedreich patients and the control group.

The plasma phospholipid pattern has been shown to be perturbed in such conditions as obstructive jaundice (Boon et al., 1969), hyperlipidemia (Noël et al., 1972) and atherosclerotic vascular disease (Gil-: lett and Besterman, 1975)., Individual phospholipids have been giver a role in the anomalies of circulating platelets reported in multiple sclerosis (Bolton et al., 1968) and polyunsaturated phospholipids have been shown to influence the behavior of rats as well as the catecholamine content of their brain (Pilecki et al., 1975). The present study did not reveal any significant differences in the phospholipid pattern between the three groups, although the relative amounts of lysophosphatidylcholine (LPC) were slightly higher in both neurological diseases. This may be of interest in view of the association of lower plasma LPC levels with atherosclerotic and thromboembolic diseases (Gillett and Besterman, 1975).

Hyperlipidemia has been associated with peripheral neuropathy in man (Fessel, 1971; Sandbank et al., 1971) and this relationship has been substantiated with the production of focal nerve damage by dietary-induced hypercholesterolemia in the rat (Sandbank and Bubis, 1973). Higher fasting serum lipid levels have been reported in amyotrophic lateral sclerosis as compared to other neuromuscular disorders (mainly Charcot-MarieTooth disease) (Mueller and Quick, 1970). In our study, only one of the Friedreich patients was found to be hypertriglyceridemic ( $\mathrm{TG} \geq 160$ $\mathrm{mg} / \mathrm{d} 1$ ). Although the mean plasma triglyceride concentration was significantly higher in this group of patients, it was still within the normal range. In contrast, plasma total cholesterol and phospholipids were
TABLE 5

PROTEIN/CHOLESTEROL RATIOS IN LIPOPROTEIII FRACTIONS

\begin{tabular}{llll}
\hline & $\begin{array}{c}\text { CONTROL } \\
(n=10)\end{array}$ & $\begin{array}{c}\text { FRIEDREICH } \\
(n=11)\end{array}$ & $\begin{array}{c}\text { CHARLEVOIX } \\
(n=5)\end{array}$ \\
\hline VLDL & $1.70 \pm 1.32^{\star}$ & $\begin{array}{l}0.80 \pm 1.07 \\
0.48 \pm 0.14^{\star \star}\end{array}$ & $0.36 \pm 0.15^{\S}$ \\
LDL & $0.58 \pm 0.22$ & $0.43 \pm 0.13$ & $0.49 \pm 0.11$ \\
HDL & $4.59 \pm 1.17$ & $2.43 \pm 0.86^{\dagger}$ & $2.11 \pm 0.52^{\dagger}$ \\
TOTAL & $1.43 \pm 0.39$ & $0.83 \pm 0.23^{\dagger}$ & $0.78 \pm 0.22^{\infty}$ \\
\hline
\end{tabular}

$*$ mean $\pm S D$

** exclusion patient SL ratio from calculations.

$+p<0.001$

$\infty p<0.02$

$5 p<0.05$ $\underline{\text { TABLE } 6}$

PERCENTAGE COMPOSITION OF HDL

\begin{tabular}{lccc}
\hline & \multicolumn{1}{c}{$\begin{array}{c}\text { CONTROL } \\
(n=10)\end{array}$} & \multicolumn{1}{c}{$\begin{array}{c}\text { FRIEDREICH } \\
(n=11)\end{array}$} & $\begin{array}{c}\text { CHARLEVOIX } \\
(n=5)\end{array}$ \\
\hline PROTEIN & $60.28 \pm 5.36^{*}$ & $46.79 \pm 7.29^{\dagger}$ & $47.55 \pm 4.79^{\dagger}$ \\
CHOLESTEROL & $13.78 \pm 2.82$ & $20.27 \pm 3.16^{\dagger+}$ & $23.36 \pm 4.85^{\dagger}$ \\
TRIGLYCERIDE & $4.69 \pm 3.27$ & $12.55 \pm 5.27^{+}$ & $6.43 \pm 4.72$ \\
PHOSPHOLIPID & $21.25 \pm 1.67$ & $20.39 \pm 1.45$ & $22.67 \pm 3.81$ \\
\hline
\end{tabular}

* mean $\pm S . D$

$t p<0.001$

t+ $p<0.01$ 
not significantly different in any of the three groups of subjects. If anything, plasma cholesterol values tended to be lower in the affected individuals.

Careful attention was given to the plasma lipoprotein fractions in view of the known association of progressive ataxia and abetalipoproteinemia (Fredrickson et al., 1972). More recently, a progressive demyelinating disorder has been reported in familial hypobetalipoproteinemia (Mars et al., 1969). The mode of inheritance is dominant in the latter and recessive in the former. Although the LDL content of plasma was significantly lower in the Friedreich cases (as measured by the protein component) and in the Charlevoix patients (as measured by the cholesterol content) as compared to the control group, these values remained well within the normal limits (Fredrickson et al., 1967). The electrophoretic pattern of total plasma lipoprotein as well as of the various lipoprotein fractions separated by ultracentrifugation and dextran sulfate precipitation did not reveal any qualitative abnormalities such as abnormal migration or unusual lipoprotein bands.

The most striking findings were made in the study of the HDL fraction. First, the total amount in circulation appeared to be low. An approximation of the total lipoprotein mass measured as the sum of protein, cholesterol and triglycerides in this density class (see Table 4) was $203.6 \mathrm{mg} / \mathrm{d} 1$ in the control group, versus 123.9 and $89.6 \mathrm{mg} / \mathrm{d} 1$ in the Friedreich and Charlevoix patients respectively. Second, the composition was grossly abnormal in the Friedreich group; it contained a larger proportion of cholesterol and triglycerides and a much smaller proportion of protein. A similar pattern was observed in Charlevoix disease, except for the excess of triglycerides which was not present, probably because of the lower plasma total triglyceride concentrations. Thus, it could be surmised that the apoprotein moiety of HDL in Friedreich's ataxia may have a greater affinity for cholesterol and triglycerides than its normal coun- terpart. This would have major implications in view of the protective role given HDL against the development of atherosclerosis and coronary heart disease (Davignon, 1977). Although present in smaller amounts, these lipoproteins could be more efficient in removing cholesterol from the tissues. If this were the case, one would expect Friedreich patients to have less atherosclerosis at autopsy as compared to normal subjects of the same age.

Our findings focus attention on the apolipoprotein moiety of HDL which should be investigated further. Examination of the apolipoprotein pattern on tetramethyl urea-polyacrylamide gels (Kane 1973; Kane et al, 1975) disclosed the presence of the expected peptides C-I, A-I, A-II, D, C-II, C-III-1, C-III-2 in a seemingly normal proportion. This should be further quantitated by densitometry. Since the Kane (1975) system does not resolve A-I from the arginine rich peptide (apo-E), other systems will need to be used for quantitative purposes, and eventually specific immunoassays. Since HDL is the natural substrate for lecithin: cholesterol acyltransferase activity (LCAT) which governs cholesterol esterification in plasma (Glomset, 1972), the relative proportion of free and esterified cholesterol should be measured as well as plasma LCAT activity in Friedreich patients. Since A-I is a potent inhibitor of plasma lipoprotein lipase activity (Ekman and Nilsson-Ehle, 1975), this enzyme should also be measured.

\section{ACKNOWLEDGMENTS}

This work was supported by the "Association Canadienne de l'Ataxie de Friedreich" and the Medical Research Council of Canada.

The authors wish to thank Mr. Michel Tremblay, Miss Lucie Boulet and Miss Murielle Paquette for their skilfull technical assistance. They are grateful to Mrs. Denise Brossard R.N., and Miss Danielle Bédard R.N., for their help with the patients and to Miss Danièle Arnaud for the typing of the manuscript.

\section{REFERENCES}

AUBRY, F., LAPIERRE, Y., NOEL, C. and DAVIGNON, J. (1971). Ultracentrifugal demonstration of floating beta-lipoprotein in type III hyperlipoproteinemia. Diagnostic value. Ann. Intern. Med. 75, 231-237.
BACHORIK. P. S.. KWITEROVIICH. P. D. and SIMON. A. (1974). Resolubilization of certain apoprotein components of human plasma high density lipoproteins in TCAfixed polyacrylamide gels during destaining in acetic acid solutions. Anal. Biochem. 60 . 631-636.

BARBEAU, A. (1976). Friedreich's ataxia 1976 - An overview. Can. J. Neurol. Sci. J. 3. 389-397.

BARBEAU, A., BRETON, G.. LEMIEUX, B. and BUTTERWORTH. R. F. (1976). Bilirubin metabolism in Friedreich"s ataxia - Preliminary investigation. Can. J. Neurol. Sci. 3. 365-372.

BARTLETT, G. R. (1959). Phosphorus assay in column chromatography. J. Biol. Chem. 234, 466-468

BLOCK. W. D.. JARRETT. K. J. and LEVINE. J. B. (1966). An improved automated determination of serum total cholesterol with a single color reagent. Clin. Chem. 12, 681-689.

BOLTON, C. H., HAMPTON, J. R, and PHILLIPSON, O. T. (1968). Platelet behaviours and plasma phospholipids in multiple sclerosis. Lancet :1. 99-104.

BOON, J., BROEKHUYSE, R. M., VAN MUNSTER, $P$. and SCHRETLEN, E. (1969). Abnormal pattern of the phospholipids of plasma and erythrocytes in four children with obstructive jaundice with abnormal spontaneous hemolysis. Clin. Chim. Acta 23, 453-456.

BOUCHARD, J. P. et al. This issue.

BRAGDON, J. H. (1960). Methods for extraction of serum lipids. In: Lipids and the steroid hormones in clinical medicine, (Sunderman, F. W., ed). J. B. Lippincott Co., Philadelphia.

COOPER, R. A., ARNER E. C.. WILEY, J. S. and SHATTIL, S. J. (1975). Modification of red cell membrane structure by cholesterol-rich lipid dispersions: a model for the primary spur cell defect. J. Clin. Invest. 55, 115-126.

DAVIGNON, J. (1977). Current views on the etiology and pathogenesis of atherosclerosis. In: Hypertension, physiopathology and treatment, (Genest, J., Koiw, E. and Kuchel, O., eds). McGraw-Hill Book Co., - New York, pp. 961-989.

DAVIGNON, J. and LANGELIER, $M$. (1971). Electrophorèse et ultracentrifugation combinées dans le diagnostic des hyperlipidémies primaires. Union Med. Can. 100, 2120-2128.

EKMAN, R. and NILSSON-EHLE, P. (1975). Effects of apolipoproteins on lipoprotein lipase activity of human adipose tissue. Clin. Chim. Acta 63, 29-35.

FESSEL, W. J. (1971). Fat disorders and peripheral neuropathy. Brain 94, 531-540.

FOLCH, J., LEES, M. and SLOANESTANLEY, G. H. (1957). A simple method for the isolation of purification of total lipids from animal tissues. J. Biol. Chem. 226, 497-509.

FREDRICKSON, D. S., GOTTO, A. M. and LEVY, R. I. (1972). Familial lipoprotein 
deficiency (abetalipoproteinemia. hypobetalipoproteinemia and Tangier disease). In: The metabolic basis of inherited disease, 3rd edition. (Stanbury, J. B.. Wyngaarden. J. B. and Fredrickson. D. S. eds). McGraw-Hill, New York, pp. 498-530.

FREDRICKSON. D. S.. LEVY. R. I. and LEES. R. S. (1967). Fat transport in liproproteins - an integrated approach 10 mechanisms and disorders. New Eng. J. Med. 276, 32-44, 94-103, 148-156, 215-226, 273-281.

GILLETT, M. P. T. and BESTERMAN, E. M. M. (1975). Plasma concentrations of lysolecithin and other phospholipids in the healthy population and in men suffering from atherosclerotic diseases. Atherosclerosis $22,111-124$.

GLOMSET, J. A. (1972). Plasma lecithin: cholesterol acyltransferase. In: Blood lipids and lipoproteins: quantitation, composition and metabolism, (Nelson, G. J.. ed). Wiley Interscience, New York, pp. 745-787.

HATCH, F. T. and LEES, R. S. (1968). Practical methods for plasma lipoprotein analysis. Adv. Lipid Res. 6. 1-68.

HAVEL, R. J., EDER, H. A. and BRAGDON. J. H. (1955). The distribution and chemical composition of ultracentrifugally separated lipoproteins in human serum. J. Clin. Invest. 34. 1345-1353.

HEILMAN, K. M. and FISHER, W. R. (1974). Hyperlipidemic dementia. Arch. Neurol. 31, 67-68.

KANE, J. P. (1973). A rapid electrophoretic technique for identification of subunit species of apoproteins in serum lipoproteins. Anal. Biochem. 53, 350-364.

KANE, J. P., SATA, T., HAMILTON, R. L. and HAVEL, R. J. (1975). Apoprotein composition of very low density lipoproteins of human serum. J. Clin. Invest. 56, 1622-1634.

KRAML, N. and COSYNS, L. (1969). A semi-automated determination of serum triglycerides. Clin. Biochim. 2. 373-380.

LAURELL. S. (1966). Method for routine determination of plasma triglycerides. Scand. J. Clin. Lab. Invest. 18, 668-672.

LEES, R. S. and HATCH, F. T. (1963). Sharper separation of lipoprotein species by paper electrophoresis in albumin. containing buffer. J. Lab. Clin. Med. 61. 518-528.

LOWRY, O. H., ROSEBROUGH, N. J., FARR, A. L. and RANDALL, R. J. (1951). Protein measurement with the folin phenol reagent. J. Biol. Chem. 193, 265-275.

MARS, H., LEWIS, L. A., ROBERTSON, A. L., BUTKUS, A. and WILLIAMS, G. H. Jr. (1969). Familial hypo- $\beta$-lipoproteinemia - a genetic disorder of lipid metabolism with nervous system involvement. Amer. J. Med. 46, 886-900.

ME'CALFE, L. D.. SCHMIDTS, A. A. and PELK, J. R. (1966). Rapid preparation of fatty acid esters from lipids for gas chromatographic analysis. Anal. Chem. 38. 514-515.

MISHKEL, M. A. and SPRITZ, N. (1969). The effect of trans-isomerized trilinolein on plasma lipids of man. In: Drugs affecting lipid metabolism, (Holmes, W. L., Carlson. L. A. and Paoletti, R. eds). Plenum Press, New York, pp. 355-364.

MUELLER, P. S. and QUICK, D. T. (1970). Studies of glucose, insulin and lipid metabolism in amyotrophic lateral sclerosis and other neuromuscular disorders. J. Lab. Clin. Med. 76, 190-201.

NOEL. C., MARCEL. Y. L. and DAVIGNON, J. (1972). Plasma phospholipids in the different types of primary hyperlipoproteinemia. J. Lab. Clin. Med. 79, 611-621.
PILECKI, R., SAMOCHOWIEC, L. and SZYSZKA, K. (1975). The influence of atherogenic diet and "essential" phospholipids upon the contents of noradrenaline and dopamine in the brain of rats and their exploratory activity. Atherosclerosis 22, 401-410.

SANDBANK, U., BECHAR, M. and BORNSTEIN, B. (1971). Hyperlipemic polyneuropathy. Acta Neuropath. 19. 290-300.

SANDBANK, U. and BUBIS, J. J. (1973). Hyperlipaemic neuropathy - Experimental study. Brain 96, 335-358.

SCANU, A. M. and EDELSTEIN, C. (1971). Solubility in aqueous solution of ethanol of the small molecular weight peptides of the serum very low density and high density lipoprotein. Relevance to the recovery problem during delipidation of serum lipoproteins. Anal. Biochem. 44, 576-588.

SHAPIRO, A. L., VINUELA, and MAIZEL. J. V. Jr. (1967). Molecular weight estimation of polypeptide chains by electrophoresis in SDS-polyacrylamide gels. Biochem. Biophys. Res. Commun. 28 , 815-820.

SIDBURY, J. B. Jr., SMITH, E. K. and HARLAN, W. (1967). An inborn error of short-chain fatty acid metabolism. J. Pediatrics 70, 8-15.

STEINBBERG, D. (1972). Phytanic acid storage disease: Refsum's syndrome. In: The metabolic basis of inherited disease, (Stanbury, J. B., Wyngaarden, J. B. and Fredrickson. D. S., eds). McGraw-Hill, New York, pp. 833-853.

WEBER, K. and OSBORN, M. (1969). The reliability of molecular weight determinations by dodecyl sulfate-polyacrylamide gel electrophoresis. J. Biol. Chem. 244, $4406-4412$ 